\title{
Wittgenstein on the Gulf Between Believers and Non-Believers
}

\author{
Paolo Tripodi
}

Received: 3 March 2012 / Accepted: 26 July 2012 /

Published online: 19 October 2012

(C) Springer Science+Business Media Dordrecht 2012

I found Annalisa Coliva's book Moore and Wittgenstein: Scepticism, Certainty, and Common Sense insightful and very rewarding, and I learnt a lot from it. In this paper, however, I focus on points of divergence. Coliva acknowledges that some sets of remarks, especially in On Certainty (see Wittgenstein 1969), appear to support a relativistic interpretation of Wittgenstein's later philosophical views. According to her, however, if we read these passages more carefully, "the first impression of dealing with an epistemic relativist should be dramatically revised" $(2010,190)$. Under her interpretation of Wittgenstein's later philosophy, Wittgenstein was not an epistemic relativist, either factual or virtual.

In this paper, with the aim of testing Coliva's thesis that Wittgenstein was not a factual epistemic relativist, I explore Wittgenstein's later remarks on religious belief, especially on credal statements such as "I believe in the Last Judgement". Preliminarily, I introduce Wittgenstein's idea that there is a gulf between (a certain kind of) believers and non-believers (section I). Then, I reject the view according to which the gulf should be explained either in terms of some sort of linguistic incommensurability (section II) or in terms of the dichotomy between the descriptive and the expressive (section III). Rather, I suggest that Wittgenstein's remarks should be read as advancing an epistemological conception of the gulf in question (sections IV and V). Furthermore, I reconstruct some aspects of Coliva's argument to the effect that Wittgenstein was not a factual epistemic relativist and argue that the collection of Wittgenstein's remarks on religious belief, however scattered, shows that Wittgenstein was a special kind of epistemic relativist (section VI). Finally, I make two brief last comments on the overall sense of the paper (section VII).

\section{Two Kinds of Religious Believers}

As is quite well known, two of Wittgenstein's pupils and friends, namely, Yorick Smythies and Elizabeth Anscombe, were Roman Catholics. Speaking of them, once

P. Tripodi $(\bowtie)$

Department of Philosophy and Education, University of Turin, Via S. Ottavio, 20 - 10124 Torino, Italy

e-mail: paolo.tripodi@unito.it 
Wittgenstein said: "I could not possibly bring myself to believe all the things that they believe" (see Malcolm 1984, 60). A few examples of things that they believe but Wittgenstein felt incapable of believing are the following: the Last Judgement (Wittgenstein 1966, 53), that Jesus is the Lord (Wittgenstein 1998, 38), Christ's Resurrection (Wittgenstein 1998, 38).

Consider the belief in the Last Judgement. In his 1938 Lectures on Religious Belief, Wittgenstein invited his students to "suppose that someone believed in the Last Judgement, and I don't" (Wittgenstein 1966, 53). Then Wittgenstein asked: "Does this mean that I believe the opposite to him, just that there won't be such a thing?", and he answered: "I would say: "not at all, or not always"” (Wittgenstein 1966, 53). Prima facie, this might appear to be nothing but the expression of Wittgenstein's being here concerned with agnosticism, rather than atheism, as if he were merely drawing his students' attention toward the case of someone (supposedly, Wittgenstein himself) who believed neither that there will be a Last Judgement nor that there will never be a Last Judgement.

It is worth noting, however, that to the question "Does this mean that I [a nonbeliever] believe the opposite to him [a believer]?", Wittgenstein answered "not at all, or not always", rather than a simpler and straightforward "no". In order to sketch an interpretation of Wittgenstein's answer, it might be useful to make a distinction by introducing two evocative names: Lev and O'Hara. Each of them refers to a different kind of believer. Lev is what Wittgenstein would have called "a honest religious thinker" (Wittgenstein 1998, 84): he has a sincere and not self-deceiving faith (which has the power to radically change his way of living) without being superstitious (that is, without claiming that his religious beliefs rest on the same kind of evidence on which our ordinary beliefs normally do rest) (Wittgenstein 1966, 56); Wittgenstein seemed to think that people such as Tolstoy or Kierkegaard had the gift of having such a kind of faith (see Monk 1990, 129-31 and Wittgenstein 1998, 61e). O'Harawhose name should evoke the Father O'Hara who in 1930 took part in a then wellknown symposium on Science and Religion - is "one of those people who make it [that is, religion] a question of science" (Wittgenstein 1966, 57): in Wittgenstein's view, his attitude is not strictly speaking religious but rather superstitious, for his religious beliefs are misleadingly based on allegedly rational and/or empirical evidence (see Wittgenstein 1966, 59).

The distinction I have just made turns out to be useful to better understand Wittgenstein's answering "not at all, or not always" to the question "Does this mean that I [a non-believer] believe the opposite to him [a believer]?" Let me begin by explaining "not always". In my view, Wittgenstein added this idiomatic expression in order to suggest that sometimes, though perhaps rarely, there are indeed cases in which one should provide a positive answer to that question, that is, cases in which one who doesn't believe in the Last Judgement does believe the opposite to one who believes in the Last Judgement. This might happen, for example, when a non-believer is confronted with O'Hara. The latter, based on rational and empirical evidence, believes a certain thing, whereas the former, based on the same kind of evidence, believes the opposite. In such a case, of course, one of them is making a mistake, and Wittgenstein thought, like most of us, that very often the one who is mistaken is the O'Hara-type believer, rather than the non-believer (Wittgenstein 1966, 59). 
The case of O'Hara was not, however, the kind of case on which Wittgenstein intended to focus in his 1938 lectures. He thought that religion (as much as ethics) is, above all, "an entirely personal matter" (Wittgenstein 1993a, 41) and, consequently, he considered O'Hara's view as a minority view among believers: in fact, Wittgenstein was reluctant to attribute that superstitious kind of belief, which he regarded as ridiculous, even to Frazer's primitives (see Wittgenstein 1993b, 131). Moreover, as Severine Schroeder pointed out, most of Wittgenstein's later remarks on religious belief were meant to "describe the kind of religious belief that he personally found appealing, comprehensible, intellectually respectable and morally attractive", namely, what I called a Lev kind of faith (see Schroeder 2007, 444, to which I am indebted in this paper).

By the same token, in the particular line of thought just considered, Wittgenstein's intention was to discuss the case in which a Lev is confronted with a non-believer. Having this case in mind, Wittgenstein answered "not at all" to the question "Does this mean that I [a non-believer] believe the opposite to him [a Lev-type believer]?", in order to emphasize that, if one answered "yes", one's answer would be not only wrong but completely misleading, so misleading that one should think that the answerer missed the point of the entire question. Wittgenstein made his point as follows: if one said "There is a German aeroplane overhead", and I said "Possibly, I'm not so sure", we should say that "we were fairly near", whereas if a (Lev-type) believer said "I believe in a Last Judgement", and I (a non-believer) said "Well, I'm not sure. Possibly", we should say that "there is a gulf between us", so that the nonbeliever is "on an entirely different plane" from Lev (Wittgenstein 1966, 53). There are two things worth noting here. First, if O'Hara said the same thing, namely, "I believe in a Last Judgement" and a non-believer said "Well, I'm not sure. Possibly", we should say, exactly like in the airplane case, that they were "fairly near". Secondly, in both the O'Hara case and the airplane case, it would be reasonable for the nonbeliever to say: "I believe the opposite".

Thus, at least prima facie, it seems that a fundamental feature of the gulf that, in Wittgenstein's view, there is between Lev and a non-believer is that, even if they don't believe the same things, they don't believe different things either (Wittgenstein 1966, 55), so that there cannot be disagreement between them: their distance from one another is much greater than in ordinary cases of disagreement. In the next three sections, I shall investigate what, more precisely, this gulf consists in.

\section{Incommensurable Languages}

Among Wittgenstein scholars, the prevailing view is what I call the "linguistic gulf view", according to which the gulf between Lev and a non-believer ultimately has linguistic roots and a linguistic nature. In this section, I consider and reject $a$ version of the linguistic gulf view, according to which not only Lev and a non-believer speak different (although perhaps homophonic) languages - for example, when they utter "Last Judgement", "Lord", "Holy Spirit", they mean something different from one another-but the former's words are not translatable in terms of the latter's vocabulary. Hence it would be impossible for the non-believer to disagree with Lev: in particular, the non-believer couldn't say "There is no reason to suppose such a thing" 
or "I believe the opposite" (Wittgenstein 1966, 53), and it would sound "utterly crazy" to say "No, I don't believe there will be such a thing" (Wittgenstein 1966, 55).

The main source of this interpretation is the Tractatus' austere conception of language, according to which the only thing we can do with meaningful sentences is to describe, or misdescribe, the facts (see Hyman 2001, 1-4). As Wittgenstein later summarized, the only way in which meaningful language works is the following: "The individual words of language name objects - sentences are combinations of such names" (Wittgenstein 1953, §1). Only by providing a picture of a possible way in which things are combined (what Wittgenstein called "a state of affairs"), a sentence is meaningful. Thus, only descriptive sentences can be meaningful. Moreover, if the pictured state of affairs obtains (or is a fact), then the sentence is true; if not, it is false. Anything, outside such austere limits of what can be said, is senseless.

But whereas propositions of logic are tautologies which are senseless but not nonsensical, any attempts to speak of values rather than facts is simply nonsensical. In particular, all religious aspects of life belong to the sphere of what cannot be said, unless one crosses the limits of sense. Therefore "one must be silent" about such matters (Wittgenstein 1971 [1922], 7), even though they are the most important and profound things in our lives, and what mattered most to Wittgenstein himself. Thus, based on a revolutionary theory of language, Wittgenstein gave new life to the traditional doctrine that religious truths are ineffable (see Hyman 2001, 4). But given that doctrine, it follows that religious assertions are untranslatable in meaningful language. Consequently, they are linguistically incommensurable. And, a disagreement between Lev and a non-believer is impossible.

I think we should resist this interpretation. For even if one takes for granted that the Tractatus' picture theory of meaning entails such an incommensurability version of the linguistic gulf view, this provides no grounds for concluding further that in his later philosophy Wittgenstein accepted the same view of religion. In fact, as is well known, in his later works Wittgenstein strongly rejected his old theory of meaning, especially the "repressive" view that denied sense and intelligibility to "the problems of life" (Wittgenstein 1971 [1922], prop. 6.52; see also Hyman 2001, 4).

Moreover, there is independent evidence that, in his 1938 lectures, Wittgenstein explicitly rejected this version of the linguistic gulf view. He came closest to formulate that view in the following remark: "It isn't a question of my [as a non-believer] being anywhere near him [the Lev-type believer], but on an entirely different plane, which you could express by saying: 'You mean something altogether different, Wittgenstein"' (Wittgenstein 1966, 53). However, he immediately clarified the just mentioned thought by saying: "The difference might not show up at all in any explanation of meaning" (Wittgenstein 1966, 53). Since the incipit of the Blue Book, this entails that the difference in question might not be a difference of meaning at all (see Wittgenstein 1958, 1). Therefore, one shouldn't associate Wittgenstein's later views on religious discourse with the incommensurability version of the linguistic gulf view.

\section{Expressivism}

Although one concedes that in the Thirties Wittgenstein dramatically changed his philosophical views on language, one might argue for another, apparently more 
plausible, version of the linguistic gulf view. One might emphasize that, the dramatic change notwithstanding, Wittgenstein continued to argue that there is a great difference - a gulf - between the descriptive uses of language, that is, the uses of language to state facts, and the non-descriptive uses of language. He ceased to think, however, that only the former but not the latter are meaningful uses of language.

Thus, one might argue, Wittgenstein replaced the doctrine that religious truths are ineffable with an expressivist view of religious beliefs, according to which credal statements, even though they have the apparent form of descriptive assertions, are actually entirely void of descriptive content and, in fact, are nothing but (somewhat metaphoric) expressions of certain attitudes towards life (see Braithwaite 1971 and Nielsen 2005). That's why Wittgenstein said that "in religious discourse we use such expressions as: 'I believe that so and so will happen,' ... differently to the way in which we use them in science" (Wittgenstein 1966, 57). In science we make assertions and hypotheses, in religious discourse we express our attitudes and emotions. Thus, under this interpretation, the gulf between non-believers and (Lev-type) believers should be conceived of as the gulf between the descriptive and the expressive. For example, when Lev says "I believe in the Last Judgement", he doesn't state that he thinks that a certain event will obtain (perhaps with a high degree of probability). Rather, he is expressing the peculiar attitude he took towards life. That's why the non-believer cannot contradict him but, at most, he can confess that he doesn't share the same attitudes, emotions and ways of living. I shall call this the expressivist version of the linguistic gulf view.

Now, some of Wittgenstein's later remarks on religion appear to support the expressivist reading. The most cited one is the following:

It appears to me as though a religious belief could only be (something like) passionately committing oneself to a system of coordinates // a system of reference" (Wittgenstein 1998, 73e).

According to the expressivist view, this remark shows that Wittgenstein held not only that the expression of a religious belief in words is neither a prediction nor a hypothesis, but also that a religious belief is entirely reducible to a passionate commitment to a system of reference. This reduction has remarkable consequences. In particular, as John Hyman argued, "if a religious belief is something like a passionate commitment to a system of reference - as opposed to a passionate commitment to the truth of an empirical proposition - then a religious belief cannot be true or false" (Hyman 2001, 6). That's why, according to the expressivist version of the linguistic gulf view, there cannot be disagreement between Lev and a non-believer.

I think, however, that if one looks closer at the key sentences in Culture and Value, one should reject the expressivist interpretation (see Schroeder 2007, 445). First, in the very next sentence following the aphorism that contains the alleged identification of a religious belief with a passionate commitment to a system of reference, Wittgenstein continues his line of argument as follows: "Hence, although it is belief, it is really a way of living, or a way of judging life" (Wittgenstein 1998, 73e). According to Schroeder, this means that "Wittgenstein stresses the importance of ... the practical dimension of religious faith, without denying that it is, or involves, also believing certain things to be true" $(2007,445)$. As I would put it, one might simply reverse Hyman's argument by saying that there's no more reason to conceive 
of a passionate commitment to the use of religious concepts as opposed to a passionate commitment to the truth of a religious belief, than there's reason to conceive of the commitment to the use of metric concepts as opposed to the commitment to the truth of a statement of length (see Hyman 2001, 6). Rather, as I will argue in the next section, in Wittgenstein's view one should conceive of a passionate commitment to the truth of a religious belief as opposed to the rational commitment to the truth of an ordinary belief.

Secondly, there are some remarks in which Wittgenstein appears to take religious beliefs, as it were, at face value. Let me cite a couple of them:

I cannot call [Jesus] Lord; because that says absolutely nothing to me.... I cannot utter the word "Lord" meaningfully. Because I do not believe that he will come to judge me (Wittgenstein 1998, 38e).

If he did not rise from the dead, then he decomposed in the grave like every human being. He is dead and decomposed. In that case he is a teacher, like any other \& can no longer help; \& we are once more orphaned \& alone (Wittgenstein 1998, 38e).

Thirdly, and more importantly, in his 1938 lectures Wittgenstein explicitly rejected the expressivist account. He invited his students to suppose that "someone, before going to China, when he might never see me again, said to me: 'We might see one another after death" (Wittgenstein 1966, 70). At first, Wittgenstein rejected what I have called the incommensurability version of the linguistic gulf view by saying: "Would I necessarily say that I don't understand him? I might say [want to say] simply, 'Yes. I understand him entirely"' (Wittgenstein 1966, 71). But on that occasion Casimir Lewy drew his attention to what I called the expressivist version of the linguistic gulf view by suggesting that "in this case, you might only mean that he expressed a certain attitude". Wittgenstein replied:

I would say 'No, it isn't the same as saying 'I'm very fond of you“ — and it may not be the same as saying anything else. It says what it says. Why should you be able to substitute anything else?" (Wittgenstein 1966, 70-1).

In this way, Wittgenstein expressly rejected the reduction of credal statements in terms of sentences that express attitudes (see Schroeder 2007, 446, and Kusch 2011, sect. 4): for the expressivist reductionist, but not for Wittgenstein, a credal statement does not say what it says, but rather it says what is said by a reductive translation of his words.

Moreover, a bit later Wittgenstein underlined that by using a sentence such as "God's eye sees everything", a believer associates a particular use with a picture (Wittgenstein 1966, 71). Although Wittgenstein took care of emphasizing "I don't want to belittle him [namely, the person who utters that sentence]", it is likely that Smythies, as a Catholic, was worried by Wittgenstein's proposing a reductive account of religion, according to which religion is nothing but the use of certain pictures. That's why Smythies felt the urge to object that "This isn't all he does-associate a use with a picture" (Wittgenstein 1966, 71). Wittgenstein immediately felt accused of a sin, reductionism, which he regarded as particularly objectionable. Thus, he reacted vehemently: 
Rubbish. I meant: what conclusions are you going to draw? etc. Are eyebrows going to be talked of, in connection with the Eye of God? 'He could just as well have said so and so' - this [remark] is foreshadowed by the word 'attitude'. He couldn't just as well have said something else. If I say he used a picture, I don't want to say anything he himself wouldn't say. I want to say that he draws these conclusions. Isn't it as important as anything else, what picture he does use? (Wittgenstein 1966, 71).

Why is it so important that Wittgenstein rejected any reductive account of credal statements? Because religious beliefs appear to have a descriptive content and, consequently, to be true or false. For example, a believer's uttering "I believe in the Last Judgement" appears to imply that the believer believes that it is true that there will be a certain event (though not a mundane one). But if reductionism is false, then such an appearance is not deceptive.

One might object, however, that under the interpretation that I am defending there would be no difference left between O'Hara and Lev. My reply is twofold. First, to say that Wittgenstein didn't propose a purely expressivist account of religious beliefs is not the same as saying that he put forward a purely descriptivist account: in fact, it seems reasonable to say that, according to Wittgenstein, a credal statement is the expression of a belief (which can be true or false), but this belief, in turn, somewhat requires a certain attitude towards life (see Schroeder 2007, 454); and, of course, in religious discourse there might be sentences which are different from credal statements and which are, in fact, purely expressive: for example, "Love one another as Jesus loves you".

Secondly, as I will show in the next section, the difference between O'Hara and Lev concerns the grounds for believing in God rather than the truth-aptness of the former's, but not of the latter's, religious beliefs.

\section{The Evidence of the Heart}

In what follows I will argue that, in Wittgenstein's view, the gulf between Lev and a non-believer is, in an important sense, epistemological rather than linguistic. When Wittgenstein dealt with the difficulty for a non-believer to make sense of a (Lev kind of) believer's credal statements, Wittgenstein emphasized, once again, that he was not proposing what I called the linguistic gulf view: "In one sense, I understand all he says - the English words "God", "separate", etc. I understand", although "I haven't got these thoughts or anything that hangs together with them" (Wittgenstein 1966, 55; see Putnam 2012, 490).

Then, he looked for a different sense in which one might say that a non-believer doesn't fully understand a believer: this happens when a non-believer quite understands the believer's words but doesn't fully understand his reasons. I call this "the epistemological gulf view":

You might say: "Well, if you can't contradict him, that means you don't understand him. If you did understand him, then you might." That again is Greek to me. My normal technique of language leaves me. I don't know whether to say they understand one another or not. 
These controversies look quite different from any normal controversies.

Reasons look entirely different from normal reasons.

They are, in a way, quite inconclusive. (Wittgenstein 1966, 55-6)

Let me elaborate a bit further. A good starting point for introducing Wittgenstein's views on the epistemology of religion could be the description we find in the Gospel of Luke of the way in which two disciples of Jesus, along the road to Emmaus, came to believe that Jesus resurrected (Gospel of Luke 24:13-34). Three days after Jesus died, while they were talking with each other about all of the things that had happened, "Jesus himself came near, and went with them. But their eyes were kept from recognizing him" (Gospel of Luke, 24:15-16). They thought that he was a stranger and told him about his own death and his own alleged resurrection, although they couldn't believe yet that the latter really happened. He talked to them about the Scriptures, but he didn't explicitly revealed his identity. Then,

they drew near to the village, where they were going, and he acted like he would go further. They urged him, saying, "Stay with us, for it is almost evening, and the day is almost over." He went in to stay with them. It happened, that when he had sat down at the table with them, he took the bread and gave thanks. Breaking it, he gave to them. Their eyes were opened, and they recognized him, and he vanished out of their sight. They said one to another, "Weren't our hearts burning within us, while he spoke to us along the way, and while he opened the Scriptures to us?" (Gospel of Luke, 24:25-34).

In the Emmaus story there are some elements of Wittgenstein's epistemological views on religion. The story shows that a (Lev-type) believer comes to believe in Jesus' Resurrection on grounds which are entirely different from ordinary and scientific ones, that is, as it were, in virtue of the "evidence of the heart" as opposed to rational and empirical evidence (see Coakley 2002, 140, Cottingham 2010, 223 and, of course, Pascal 1976 [1670]). The people of Emmaus didn't recognize Jesus until they had a peculiar experience of inner transformation, partly based on their lives (that is, on their being disciples of Jesus, their suffering for his death, their dealing with a stranger, their being behind him, their being induced by him to focus on the Scriptures, thus having their hearts "burning within them"), partly based on the effects of something mysterious that just "happened" to them (that is, something connected to Jesus' act of taking the bread, giving thanks, breaking it and giving it to them). Their ordinary perception and memory were almost of no use to them.

There are several passages that show that Wittgenstein drew an epistemological distinction between the evidence of the heart, which provides grounds for the Lev kind of religious belief, on the one hand, and rational and empirical evidence, which provides grounds for our ordinary and scientific beliefs, on the other hand. Not only did Wittgenstein remark that "if Christianity is the truth, then all the philosophy about it is false" (Wittgenstein 1998, 89e); not only did he think that what was "ludicrous about O'Hara" was "his making it appear to be reasonable" (Wittgenstein 1966, 58), whereas he would have definitely called him superstitious and "unreasonable" (Wittgenstein 1966, 59). But Wittgenstein also added that, by contrast, he would 
not have called unreasonable the Lev kind of religious believers, even though "they base things on evidence which taken in one way would seem exceedingly flimsy" (Wittgenstein 1966, 57-8) (where "taken in one way" should mean something like "taken in the ordinary - that is, rational and empirical - sense"). In his view, faith cannot be the result of ordinary evidence: even ordinary indubitability would not be enough in that case, for, Wittgenstein said, it "wouldn't be enough to make me change my whole life" (Wittgenstein 1966, 57). Indeed, Wittgenstein regarded faith as the result of a life rather than as the result of ordinary evidence (cf. Wittgenstein 1966, 53-4 and Wittgenstein 1998, 38e):

Christianity is not based on a historical truth, but presents us with a (historical) narrative \& says: now believe! But not, believe this report with the belief that is appropriate to historical report,- - but rather: believe, through thick \& thin \& you can do this only as an outcome of a life. Here you have a narrative, don't take the same attitude to it as you take other historical narratives! Make a quite different place in your life for it.... (Wittgenstein 1998, 37e).

Among other things Christianity says, I believe, that sound doctrines are all useless. That you have to change your life. (Or the direction of your life.) (Wittgenstein $199861 \mathrm{e}$ ).

On Wittgenstein's view, only passion and love can bring about such a radical change in one's life (cf. Wittgenstein 1998, 38e):

For a sound doctrine need not seize you; you can follow it, like a doctor's prescription. - But here you have to be seized \& turned around by something. ...

Wisdom is passionless. By contrast Kierkegaard calls faith a passion. (Wittgenstein 1998, 61e)

... If I am to be REALLY redeemed,-I need certainty - not wisdom, dreams, speculation - and this certainty is faith. And faith is faith in what my heart, my soul, needs, not my speculative intellect. ... Perhaps one might say: Only love can believe the Resurrection. Or: it is love that believes the Resurrection. (Wittgenstein 1998, 38e-39e)

In the light of the above passages, one might associate Wittgenstein with the idea that there are some religious "truths whose accessibility conditions include certain requirements as to the attitude of the subject" (Cottingham 2010, 223). For example, it is likely that Wittgenstein had religious truth in mind, when he wrote:

One cannot speak the truth;-if one has not yet conquered oneself. One cannot speak it - but not, because one is still not clever enough. (Wittgenstein 1998, $41 \mathrm{e}$; see also $39 \mathrm{e}$ )

\section{Justificatory Role and Intelligibility of the Believer's Grounds}

In the previous section, I argued to the effect that, in Wittgenstein's view, the gulf between (Lev-type) believers and non-believers has an epistemological nature: 
religious belief relies on non-ordinary grounds (such as passion and love) rather than on rational and empirical grounds. This argument gives rise to the following two questions:

i. How should we conceive - in Wittgenstein's view—of such non-ordinary grounds, on which a Lev kind of believer comes to believe, for example, that there will be a Last Judgement: as reasons or rather as mere causes? In other words: do such grounds have a somewhat justificatory role to play?

ii. In Wittgenstein's view, are the believers' grounds somewhat intelligible to nonbelievers?

In what follows, I shall try to answer both questions.

Justification On the one hand, it might seem that, in Wittgenstein's view, a Lev kind of believer's grounds share some features with causes rather than with reasons. First, one can be impressed by them (see Wittgenstein 1998, 52e). Secondly, they depend on something that can just happen to one (see Wittgenstein 1998, 38e). Thirdly, there are some passages in which Wittgenstein appeared explicitly to reject the idea that religious beliefs are somewhat justified. For example, he wrote:

Religion says: Do this! Think like that! but it cannot justify this and it only need try to do so to become repugnant; since for every reason it gives, there is a cogent counter-reason. (Wittgenstein 1998, 34e; see also Wittgenstein 1966, 56)

All this notwithstanding, I think that we should resist the conclusion that Wittgenstein regarded reliance on the evidence of the heart as a merely genetic explanation of one's religious beliefs. First, one can be impressed by a certain thing and, at the same time, consider that thing as a reason (to act and/or to believe), rather than a cause. For example, Wittgenstein wrote: "I can imagine that the mere report of the words \& life of a saint can make someone to believe the reports that the trees bowed. But I am not so impressed" (Wittgenstein 1998, 52). The point of this remark is not that what impresses the believer is just the cause of his faith, but rather that the believers' grounds can be quite opaque to non-believers, for the former "reasons look entirely different from normal reasons" (Wittgenstein 1966, 56).

Secondly, it is true that, in Wittgenstein's view, faith is something that can somewhat mysteriously happen to one. It seems clear to me, however, that Wittgenstein also thought that one must be somewhat free to accept (or to reject) certain things or events as grounds for believing. Otherwise, it would be difficult to make sense of remarks such as the following, in which Wittgenstein-who once wrote that "What is Good is Divine too. That, strangely enough, sums up my ethics" (Wittgenstein 1998, 5e) - suggested that one cannot have faith unless one undertakes a radical moral renewal and, consequently, that one can be urged to change one's life, in order to become capable of believing:

Look after making yourself more decent! In your present state, you are quite incapable of understanding what may be the truth here. (Wittgenstein $1998,35$ e, see also $15 \mathrm{e}-16 \mathrm{e}, 30 \mathrm{e}, 52 \mathrm{e})$

Moreover, Wittgenstein describes as follows the situation in which one has, as it were, the opportunity to become a believer: 
It is though I had lost my way \& asked someone the way home. He says he will show me and walks with me along a nice smooth path. This suddenly comes to an end. And now my friend says: "All you have to do now is to find the rest of the way home from here" (Wittgenstein 1998, 53e; see also 73e)

Finally, as Jacques Bouveresse suggested, Wittgenstein was interested in genetic explanations, such as those of Nietzsche or Freud, only to the extent that "they do not reveal a real relationship between two things which at first sight are unrelated, but they do suggest a formal connection between two concepts" (Bouveresse 2007, 271).

In virtue of all the above evidence, I'd like to suggest that when Wittgenstein said that "Religion says: Do this! Think like that! but it cannot justify this" (Wittgenstein 1998, 34e), he used the verb "to justify" in a narrow sense (the only sense O'Hara was capable to attach to that word), that is, as equivalent to "justify in terms of ordinary reasons". By the same token, when he said that "if there were evidence, this would in fact destroy the whole business" of religion (Wittgenstein 1966, 56), he used the word "evidence" in the same, narrow, sense. But this leaves open the possibility that he held that there is also a broad sense of the term, which includes a different kind of justification, based on love, passion and certain basic religious experiences (see Wittgenstein 1966, 58).

To sum up: in Wittgenstein's view there are grounds for calling "reasons" the believer's grounds, though they are entirely different from ordinary reasons. Let me now consider the idea that a believer's reasons are ultimately unintelligible to a non-believer.

Intelligibility On the one hand, I concede that in Wittgenstein's view the believer's grounds are partly opaque (or mysterious) to the non-believer (Wittgenstein 1966, 56). On the other hand, however, this is not to deny that even a sensitive non-believer (like Wittgenstein himself) has a partial but quite deep understanding of the believer's grounds. In fact, Wittgenstein put forward the idea that there are different degrees of religiosity and, accordingly, different degrees of understanding of religious matters:

In religion it must be the case that corresponding to every level of devoutness there is a form of expression that has no sense at the lower level. For those still at the lower level this doctrine, which means something at the higher level, is null \& void; it can only be understood wrongly, \& so these words are not valid for such a person. (Wittgenstein 1998, 37e)

Thus, Wittgenstein didn't think that even a sensitive non-believer cannot make a quite good sense of the believer's reasons, but rather that it is extremely difficult to get such an understanding. To this effect, he wrote:

The honest religious thinker is like a tightrope walker. It almost looks as though he were walking on nothing but air. His support is the slenderest imaginable. And yet it really is possible to walk on it. (Wittgenstein 1998, 84e; see also 56e).

Wittgenstein made three main points about the extreme difficulty (rather than the impossibility) for a non-believer like himself of accepting, or just of making sense of, a believer's grounds for believing. First, Wittgenstein warned us, perhaps partly as a 
consequence of such difficulty, to pay respect to religious beliefs (see Wittgenstein 1998, 95e). Secondly, he provided us with a reason why it is so difficult for one to come to believe: the reason is that one's faith is strictly associated with one's life, so that one cannot get the former unless one radically changes the latter. For example, one's level of religiosity has to do with one's way of living. In Wittgenstein's words:

Paul's doctrine of election by grace for instance is at my level irreligiousness, ugly nonsense. So it is not meant for me since I can only apply wrongly the picture offered to me. If it is a holy $\&$ good picture, then it is so for a quite different level, where it must be applied in life quite differently than I could apply it. (Wittgenstein 1998, 37e).

Moreover, Wittgenstein thought that life can educate one to understand the believer's reasons and even to believe the believer's truths. To this effect he wrote:

"Convincing someone of God's existence" is something you might do by means of a certain upbringing, shaping his life in such \& such a way.

Life can educate you to "believing in God". And experiences too are what do this but not visions, or other sense experiences, which show us the "existence of this being”, but e.g. sufferings of various sorts. (Wittgenstein 1998, 97e, but see also $37 \mathrm{e}, 38 \mathrm{e}, 61 \mathrm{e})$.

But what are, more precisely, such basic religious experiences, in Wittgenstein's view? A first experience, which somewhat provides a ground for believing, is the experience of "wonder at the existence of the world" (what makes one inclined to say "how extraordinary that anything should exist") (Wittgenstein 1993a, 41): not wondering at the existence of this or that thing, but at the very existence of the world. This experience might be a ground for believing that there is a Creator (see Schroeder 2007, 441 ff.).

A second experience of the same kind is "the experience of feeling absolutely safe" (what makes one inclined to say "I am safe, nothing can injure me whatever happens") (Wittgenstein 1993a, 41): not safe from this or that dangerous event, but safe whatever happens (see Malcolm 1984, 58). This experience might give rise to the belief that we trust in God. That's why Wittgenstein also wrote that "Religious faith . . . is a trusting' (Wittgenstein 1998, 82e).

A third experience is the "recognition of sin" (Wittgenstein 1998, 32e). Not only did Wittgenstein write that "People are religious to the extent that they believe themselves to be not so much imperfect as sick (Wittgenstein 1998, 51e)" and that "Anyone who is half-way decent will think himself utterly imperfect, but the religious person thinks himself wretched" (Wittgenstein 1998, 51e), but he also said that

Christianity is not a doctrine, ... but a description of something that actually takes place in human life. For 'recognition of sin' is an actual occurrence \& so is despair \& so is redemption through faith. (Wittgenstein 1998, 32e)

This experience might provide one with grounds for opening one's "heart to God in remorseful confession" (Wittgenstein 1998, 52e).

Another experience is the experience of distress and absolute loneliness. Wittgenstein wrote: "The Christian religion is only for the one who needs infinite 
help, that is only for the one who suffers infinite distress. ... Christian faith - so I believe-is refuge in this ultimate distress" (Wittgenstein 1998, 52e). In such cases it might happen that one "loses his dignity as someone special \& so becomes like a child" (Wittgenstein 1998, 52e), and starts feeling the need of God's help.

A further experience is a man's inclination "to take everything that happened to him as a reward or punishment" (Wittgenstein 1966, 54). For example, "If he is ill, he may think: 'What have I done to deserve this?"' (Wittgenstein 1966, 54) or "This is a punishment" (Wittgenstein 1966, 55). This experience might make one to believe that there will be a Last Judgement or to say, like Jukundus in Gottfried Keller's Das verlorne Lachen, "The Lord hath given, the Lord hath taken away" (Wittgenstein 1998, 54e).

As Schroeder underlined, "such religious or proto-religious emotions and attitudes are not in themselves religious belief' $(2007,452)$. Sometimes the further step is not taken, and "this was Wittgenstein's case": in this case, one can, at most, play, as it were, with a religious belief, without committing oneself to it (see Wittgenstein 1998, 38). Other times, however, "the further step is taken: a certain emotional attitude not only expresses itself in religious pictures and ideas, but those pictures and ideas are also believed to be literally true" (Schroeder 2007, 452). I regard Schroeder's remark as not only illuminating but also true. However, my above description of Wittgenstein's views on such special human experiences was just meant to show two things: that Wittgenstein regarded such experiences as possible grounds for religious beliefs; and that he showed that a non-believer like himself could have a quite deep comprehension of them.

\section{Wittgenstein's Relativism Reconsidered}

Keeping in mind the above interpretation of Wittgenstein's later remarks on religious beliefs, I now come to consider Coliva's argument to the effect that Wittgenstein was not an epistemic relativist (see Coliva 2010, 188-203). Coliva provides the following definition (or, perhaps, explication) of "epistemic relativism": someone is an epistemic relativist just in case one believes that there could be, either in principle or as a matter of fact,

(a) at least one epistemic system, call it B, alternative to our own epistemic system, call it A,

$\&$

(b) A and B are equally correct

$\&$

(c) we are able to understand B

$\&$

(d) if we met people who adopt B, we could not rationally persuade them to abandon some of their hinges in favour of ours

$\&$

(e) nonetheless, we should not revise our translation of some of their words. 
The above definition needs some qualification. First, by "epistemic system" in (a) we should mean either a central core of beliefs in hinges propositions and/or a set of methods and criteria of justification (see Coliva 2010, 179-81, 188, 192-7). Secondly, by "B is alternative to A" we should mean that A and B are mutually incompatible (see Coliva 2010, 198, 232). In the third place, the sentence "A and B are equally correct" in (b) should be interpreted broadly, as to also include the case in which A and B are equally neither correct nor incorrect (or so I assume, since I agree with Coliva in regarding Wittgenstein as an anti-foundationalist who thought that our beliefs in hinges propositions are ungrounded, and that there couldn't be meta-criteria to establish a ranking of criteria of justification). Furthermore, we should take "we are able to understand B" in (c) as being roughly equivalent to "we are able to conceive of B in detail" (see 2010, 197-8, 201), "we are able to make sense of B" (see 2010, 201), "B is intelligible to us" (see 2010, 198), and " $\mathrm{B}$ is comprehensible from our own standpoint" (see 2010, 203). Finally, the phrase "to rationally persuade someone" occurring in (d) should be intended as meaning the same as "to persuade someone by providing him or her with ordinary or scientific evidence" (see 2010, 188 , 197), whereas we should take "we should not revise our translation" in (e) to mean that we should have no reason to explain away apparent cases of faultless disagreement and deep misunderstanding by attributing a different meaning to the words of the one who adopts B (see 2010, 197).

Now, it seems to me that, given Coliva's definition of what being an epistemic relativist consists in, and given my thesis according to which, in Wittgenstein's view, the gulf between a Lev kind of believer and a non-believer has an epistemological rather than a linguistic nature, it follows that Wittgenstein was, after all, an epistemic relativist of some sort. Or so I argue. In what follows, I will briefly comment on each point of Coliva's definition.

(a) Incompatible standards of justification. Consider the statement "There will be a Last Judgement". For the sake of brevity, call it " $p$ ". As I argued above, Wittgenstein thought that, on the one hand, a Lev kind of believer believes $p$ to be true, whereas a non-believer cannot assent to it; but he was also convinced, on the other hand, that as a hypothesis $p$, as well as many other religious truths, is extremely implausible (see Schroeder 2007, 443). This is one reason why Wittgenstein thought that O'Hara's attitude was ludicrous: for example, if O'Hara would have uttered the sentence "Particles will rejoin in a thousand years", he would have made nothing but a bad, unjustified, para-scientific prediction (see Wittgenstein 1998, 53). I take this to be enough to reach the conclusion that Lev's system of beliefs is incompatible with both ordinary and scientific systems of beliefs.

Furthermore, according to Wittgenstein the gulf that there is between a Lev kind of believer and a non-believer should be conceived of in epistemological terms. This means, first, that Wittgenstein thought that the Lev kind of believer's grounds have some sort of justificatory role (broadly conceived) to play and, second, that the believer's grounds (that is, the evidence of the heart) are entirely different from the ordinary ones. This is the other reason why Wittgenstein considered O'Hara's view as ludicrous: O'Hara misleadingly regarded his religious beliefs as resting on the same kind of evidence as ordinary and 
scientific beliefs. As Schroeder would put it, there seems to be "an unresolved tension in Wittgenstein's philosophy of religion" (2007, 442), a tension, I would say, between two theses: as a hypothesis, $p$ is a lost cause; based on the evidence of the heart, one can somewhat justify $p$. As far as I can see, there is a quite appropriate label for such a tension: "epistemic relativism".

Coliva, however, has two main arguments to the effect that Wittgenstein was not a factual epistemic relativist. The first argument is that, even in the relativistfriendly actual cases, in which conditions (b), (c) and (e) appear to be satisfied, Wittgenstein believes that both condition (d) and (as a consequence) condition (a) are not satisfied. For example, Coliva (2010, 192-5) underlines that in his Remarks on Frazer's "Golden Bough" Wittgenstein makes it clear that it is a mistake to regard those primitive people who form beliefs by using methods that don't rely on evidence but on Divination as having a fundamentally different knowledge of nature from us: rather, Wittgenstein tells us, only their magicthat is, the religious and symbolic element of their practices, as distinct from the epistemic element-is different (see Wittgenstein 1993b, 141).

To this argument I have two replies. First, it is controversial whether Wittgenstein, in the Remarks on Frazer, put forward an expressivist view of religious beliefs (see Clack 2004). Secondly, even if one grants that, in Wittgenstein's later views, Frazer's primitives have neither a fundamentally different knowledge of nature nor, what is more relevant, a fundamentally different method of justification than ours, nonetheless it does not follow that, in Wittgenstein's view, the same also applies to Christian believers of the kind he was most interested in.

Coliva's second argument is that, in Wittgenstein's view, there are cases in which conditions (b), (c), (d) and (e) are allegedly satisfied; in such cases, however, condition (a) is not satisfied. Coliva mentions the Catholic's acceptance of the dogma of the Holy Trinity, which "goes against the hinge that something can't be one and three at once" (Coliva 2010, 196). Then she cites a passage in which Wittgenstein said that a "dogma is expressed in the form of assertion, and is unshakable, but at the same time any practical opinion can be made to accord with it" (Wittgenstein 1998, 32e-33e). Thus, she argues, in Wittgenstein's view it is a mistake to regard religious believers as having a different logic (let alone a different method of justification) than ours, for the two spheres - the religious and the mundane - are sufficiently insulated from one another (see Coliva 2010, 196).

Before replying to Coliva, let me cite Wittgenstein's entire remark (which she also cites in the book):

If certain graphic propositions for instance are laid down for human beings as dogmas governing thinking, namely in such a way that opinions are not thereby determined, but the expression of opinions is completely controlled, this will have a very strange effect. People will live under an absolute, palpable tyranny, yet without being able to say they are not free. I think the Catholic Church does something like this. For dogma is expressed in the form of an assertion \& is unshakable, $\&$ at the same time any practical opinion can be made to accord with it; admittedly this is easier in some cases, more difficult in others. It is not a wall setting limits to belief, but like a brake which in practice however serves 
the same purpose; almost as though someone attached a weight to your foot to limit your freedom of movement. This is how dogma becomes irrefutable \& beyond the reach of attack. (Wittgenstein 1998, 32e-33e).

It seems to me that this citation doesn't put in question my interpretation of Wittgenstein's later remarks on religious belief. Why? Because the topic seems to be different. As far as I can see, here Wittgenstein is not concerned with faith but rather with opinion (which he considers to be an entirely different matter, see Wittgenstein 1966, 57); not with sincere "inner" belief but with the merely exterior (and, therefore, perhaps insincere) expression of belief; not, in Kierkegaardian terms, with the faith of a "single individual" (see Kierkegaard 1983 [1843])—what I called a Lev kind of faith-but with the Church's intervention on proselytes. Moreover, even if one grants that the dogma of the Holy Trinity can be insulated from any practical and ordinary belief, so that one can believe that the former is an extraordinary case in which something can be at the same time each of three different things, without ever wondering (and even making sense of the question) whether, say, in everyday life a certain table (or paper or hand) can be identical to more than one different thing, one can nonetheless hold that there is an epistemological gulf that separates a believer (of the Lev kind) from a non-believer about the content of the very statement "God is one in three persons".

(b) Anti-foundationalism. I think that Coliva persuasively argued that, in Wittgenstein's view, any epistemic system is neither correct nor incorrect (see 2010, 201-2).

(c) Intelligibility and understanding. I hope to have shown above that, in Wittgenstein's view, the gulf between believers and non-believers is, in an important sense, not linguistic, and also that a sensitive non-believer can have a quite deep understanding of the believer's peculiar grounds.

(d) No rational persuasion. A believer of the Lev kind cannot be convinced by rational persuasion, simply because his faith is based on an entirely different kind of grounds (see Wittgenstein 1966, 56).

(e) No revision of translation. If, as I argued, the gulf is not linguistic, then there's no need, for a non-believer, to revise his translation of the believer's words.

\section{Two Marginal Notes}

In this paper I have argued that Wittgenstein's later collection of remarks on a peculiar kind of religious beliefs should induce us to conceive of him as a sort of factual epistemic relativist. I didn't try, however, to evaluate Wittgenstein's views on religion. In other words, my goal was neither to support nor to criticize them. (For a sympathetic approach to Wittgenstein's views, see Malcolm 1997 and Plant 2011. For criticisms, see Nielsen 2005 [1967], Glock 1996 and Hyman 2001).

I said that "epistemic relativism" could be a good label for Wittgenstein's views on religion. I do not wish to say, however, that Wittgenstein himself would have liked such a label, not least because it sounds too much as a philosophical theory. ${ }^{1}$ In my

\footnotetext{
${ }^{1}$ Neither I wish to suggest that my reading of Wittgenstein's views on religious belief has wider implications, let alone that it is just a special case that should be generalized to the whole of Wittgenstein's later philosophy.
} 
view, however, Wittgenstein's remarks on what I called the Lev kind of Christian faith, however scattered and partly private, provided us, as it were, with all the ingredients to make an epistemic relativist cake. ${ }^{2}$

\section{References}

Bouveresse, J. (2007). Wittgenstein's critique of Frazer, "Ratio", new series, XX, 357-376.

Braithwaite, R. (1971). An empiricist's view of the nature of religious belief. In B. Mitchell (ed.), The philosophy of religion (pp. 72-91), Oxford: OUP.

Clack, B. R. (2004). Wittgenstein and magic. In R. L. Arrington and M. Addis (eds.), Wittgenstein and philosophy of religion (pp. 12-28). London: Routledge.

Coakley, S. (2002). Powers and submissions: Spirituality, philosophy and gender. Oxford: Blackwell.

Coliva, A. (2010). Moore and Wittgenstein. Scepticism, certainty and common sense. London: Palgrave Macmillan.

Cottingham, J. (2010). Wittgenstein, religion, and analytic philosophy. In H.-J. Glock and J. Hyman (eds.), Wittgenstein and analytic philosophy, essays for P.M.S. Hacker. Oxford: OUP

Glock, H.-J. (1996). A Wittgenstein dictionary. Oxford: Blackwell.

Gospel of Luke. In New Revised Standard Version (NRSV) of the Bible.

Hyman, J. (2001). The gospel according to Wittgenstein. In R. L. Arrington \& M. Addis (Eds.), Wittgenstein and philosophy of religion (pp. 1-11). London: Routledge.

Kierkegaard, S. (1983). [1843], Fear and Trembling, [original Danish title: Frygt og Baeven], translated by Howard V. Hong and Edna H. Hong. Princeton: Princeton University Press.

Kusch, M. (2011). Disagreement and picture in Wittgenstein's 'Lectures on religious belief'. In R. Heinrich et al. (eds.), Image and imaging in philosophy, science and the arts, Vol. 1 (pp. 35-58). Frankfurt: Ontos Verlag.

Malcolm, N. (1984). Ludwig Wittgenstein: a memoir (2nd ed.). Oxford: OUP.

Malcolm, N. (1997). Wittgenstein: a religious point of view? London: Routledge.

Monk, R. (1990). Ludwig Wittgenstein: the duty of genius. London: Macmillan, 1990.

Nielsen, K. (2005). Wittgensteinian fideism. In K. Nielsen, K. and D. Z. Phillips (eds.), Wittgensteinian fideism? (pp 210-38). London: SCM Press.

Pascal, B. (1976) [1670], Pensées, Paris: GF-Flammarion.

Plant, B. (2011). Religion, relativism, and Wittgenstein's naturalism. International Journal of Philosophical Studies, 19(2), 177-209.

Putnam, H. (2012). Wittgenstein: a reappraisal. In M. De Caro and D. Macarthur (eds.) Philosophy in the age of science. Physics, mathematics, and skepticism (pp. 482-94). Harvard: Harvard University Press.

Schroeder, S. (2007). The tightrope walker. "Ratio" (new series) XX, 442-463.

Wittgenstein, L. (1953). Philosophical investigations, tr. by G. E. M. Anscombe, 2nd edition. Oxford: Basil Blackwell.

Wittgenstein, L. (1958). The blue and brown books. Oxford: Blackwell.

Wittgenstein, L. (1966). Lectures and conversations on aesthetics, psychology and religious belief. Oxford: Blackwell.

Wittgenstein, L. (1969). On certainty. Oxford: Blackwell.

Wittgenstein, L. (1971 [1922]). Tractatus Logico-Philosophicus, tr. by D.F. Pears and B. F. McGuinness. London: Routledge and Kegan Paul.

Wittgenstein, L. (1993a). A lecture on ethics. In J. C. Klagge \& A. Nordmann (Eds.), Philosophical occasions 1912-1951 (pp. 37-44). Indianapolis: Hackett.

Wittgenstein, L. (1993b). Remarks on Frazer's ‘Golden Bough'. In J. C. Klagge \& A. Nordmann (Eds.), Philosophical occasions 1912-1951 (pp. 118-155). Indianapolis: Hackett.

Wittgenstein, L. (1998). Culture and value, rev. ed., tr. by P. Winch. Oxford: Blackwell.

\footnotetext{
${ }^{2}$ I wish to thank Diego Marconi and Carlo Penco for their comments on an earlier draft of this paper, and Massimo Ferrari and Hanjo Glock for their remarks on a particular exegetical question.
} 